Check for updates

Cite this: RSC Adv., 2019, 9, 11322

\title{
Rechargeable aluminum batteries: effects of cations in ionic liquid electrolytes $\uparrow$
}

\author{
Guanzhou Zhu, (D) a Michael Angell, ${ }^{a}$ Chun-Jern Pan, ${ }^{\text {ab }}$ Meng-Chang Lin, ${ }^{c}$ Hui Chen, ${ }^{c}$ \\ Chen-Jui Huang, (DD b Jinuan Lin, ${ }^{\mathrm{a}}$ Andreas J. Achazi, (D) df Payam Kaghazchi, \\ Bing-Joe Hwang (iD ${ }^{\mathrm{b}}$ and Hongjie Dai ${ }^{* a}$
}

Room temperature ionic liquids (RTILs) are solvent-free liquids comprised of densely packed cations and anions. The low vapor pressure and low flammability make ILs interesting for electrolytes in batteries. In this work, a new class of ionic liquids were formed for rechargeable aluminum/graphite battery electrolytes by mixing 1-methyl-1-propylpyrrolidinium chloride $\left(\mathrm{Py} 13 \mathrm{Cl}\right.$ ) with various ratios of aluminum chloride $\left(\mathrm{AlCl}_{3}\right)$ $\left(\mathrm{AlCl}_{3} / \mathrm{Py} 13 \mathrm{Cl}\right.$ molar ratio $=1.4$ to 1.7$)$. Fundamental properties of the ionic liquids, including density, viscosity, conductivity, anion concentrations and electrolyte ion percent were investigated and compared with the previously investigated 1-ethyl-3-methylimidazolium chloride ( $\left.\mathrm{EMIC}-\mathrm{AlCl}_{3}\right)$ ionic liquids. The results showed that the $\mathrm{Py} 13 \mathrm{Cl}-\mathrm{AlCl}_{3}$ ionic liquid exhibited lower density, higher viscosity and lower conductivity than its $\mathrm{EMIC}-\mathrm{AlCl}_{3}$ counterpart. We devised a Raman scattering spectroscopy method probing ILs over a Si substrate, and by using the Si Raman scattering peak for normalization, we quantified speciation including $\mathrm{AlCl}_{4}^{-}, \mathrm{Al}_{2} \mathrm{Cl}_{7}^{-}$, and larger $\mathrm{AlCl}_{3}$ related species with the general formula $\left(\mathrm{AlCl}_{3}\right)_{n}$ in different IL electrolytes. We found that larger $\left(\mathrm{AlCl}_{3}\right)_{n}$ species existed only in the Py13Cl-AlCl 3 system. We propose that the larger cationic size of Py $13^{+}\left(142 \AA^{3}\right)$ versus EMI $\left(118 \AA^{3}\right)$ dictated the differences in the chemical and physical properties of the two ionic liquids. Both ionic liquids were used as electrolytes for aluminum-graphite batteries, with the performances of batteries compared. The chloroaluminate aniongraphite charging capacity and cycling stability of the two batteries were similar. The Py $13 \mathrm{Cl}-\mathrm{AlCl} 3$ based battery showed a slightly larger overpotential than $\mathrm{EMIC}-\mathrm{AlCl}_{3}$, leading to lower energy efficiency resulting from higher viscosity and lower conductivity. The results here provide fundamental insights into ionic liquid electrolyte design for optimal battery performance.

Received 28th January 2019

Accepted 1st April 2019

DOI: $10.1039 / c 9 r a 00765 b$

rsc.li/rsc-advances storage devices. In addition to LIBs, other types of battery have been developed including sodium-ion batteries, zincion batteries, magnesium-ion batteries and aluminum-ion batteries (AIBs) that could complement or serve as alternatives to each other. ${ }^{1-9}$

The electrolyte lies at the heart of a battery. With the advances in battery technology, the development of a safe and stable electrolyte is critically important. Room temperature ionic liquids (RTILs) are safe and sufficiently conducting, useful as battery electrolytes. ${ }^{\mathbf{1 0 - 1 4}}$ Various ionic liquids have been investigated for different types of batteries, including LIB and AIB.,15,16 Our group has developed rechargeable Al-graphite battery based on two types of electrolytes, an IL electrolyte made by mixing 1-ethyl-3-methylimidazolium chloride (EMIC) and $\mathrm{AlCl}_{3}$ and an quasi IL or deep-eutectic solvent (DES) by mixing urea with $\mathrm{AlCl}_{3}{ }^{7-9}$ The batteries operate by reversible redox of $\mathrm{Al}$ at the negative $\mathrm{Al}$ foil electrode, and reversible carbon redox through chloroaluminate anion intercalation and deintercalation at the graphite positive electrode..$^{-9,17-19}$ Still, much room exists in developing new IL electrolytes to improve Al battery, and especially, to understanding the relations

$\dagger$ Electronic supplementary information (ESI) available. See DOI: $10.1039 / \mathrm{c} 9 \mathrm{ra} 00765 \mathrm{~b}$ 
between the composition, physical properties of IL electrolytes and battery performance.

Herein, we report a new series of ionic liquids formed by mixing 1-methyl-1-propylpyrrolidinium chloride and $\mathrm{AlCl}_{3}$ at various ratios $\left(\mathrm{AlCl}_{3} / \mathrm{Py} 13 \mathrm{Cl}\right.$ ratios: $\left.1.4,1.5,1.6,1.7\right)$. The electrolytes exhibited different physical and chemical properties

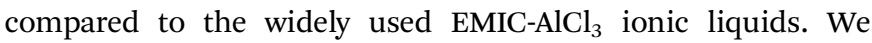
devised an approach to probe and quantify the species in both ionic liquids containing monomeric $\mathrm{AlCl}_{4}{ }^{-}$anion and dimeric $\mathrm{Al}_{2} \mathrm{Cl}_{7}{ }^{-}$anion. We found that larger $\mathrm{AlCl}_{3}$ related species in the form of $\left(\mathrm{AlCl}_{3}\right)_{n}$ existed only in $\mathrm{Py} 13 \mathrm{Cl}-\mathrm{AlCl}_{3}$ ionic liquid and were absent in $\mathrm{EMIC}^{-\mathrm{AlCl}_{3}}$. In addition, the overall concentration of $\mathrm{AlCl}_{4}{ }^{-}$and $\mathrm{Al}_{2} \mathrm{Cl}_{7}{ }^{-}$and ion percent were lower in the $\mathrm{Py} 13 \mathrm{Cl}-$ $\mathrm{AlCl}_{3}$ system. The difference in cation size (Py13 ${ }^{+}: 142 \AA^{3}$ versus $\mathrm{EMI}^{+}$: $118 \AA^{3}$ ) was likely responsible for the differences in the


using Py13Cl- $\mathrm{AlCl}_{3}$ electrolyte showed lower energy and voltage efficiency as a result of their larger overpotential resulted from higher viscosity and lower ionic conductivity with the presence of large $\left(\mathrm{AlCl}_{3}\right)_{n}$ species in the ionic liquid. Our results help to shed light into electrolyte design for $\mathrm{Al}$ batteries.

\section{Results}

\section{Structure, density, viscosity, and conductivity of ILS}

Fig. 1a shows the structure of Py13Cl and EMIC. DFT calculations (B3LYP-D3BJ/def2-TZVP) were performed to determine the geometrically optimized structure and the electrostatic potential maps of $\mathrm{Py}_{1} 3^{+}, \mathrm{EMI}^{+}$and $\mathrm{AlCl}_{4}{ }^{-}$(Fig. S1†). Subsequently the sizes of the molecules were determined based on the van der Waals radii to be $142 \AA^{3}, 118 \AA^{3}$, and $105 \AA^{3}$, respectively. $\mathrm{AlCl}_{4}{ }^{-}$size ratio to $\mathrm{Py} 13^{+}$and $\mathrm{EMI}^{+}$is 0.74 and 0.89 , respectively.

We first measured the density of ionic liquids formed by mixing $\mathrm{AlCl}_{3}$ with $\mathrm{Py} 13 \mathrm{Cl}$ and EMIC respectively at various molar ratios (Fig. 1b). The $\mathrm{EMIC}-\mathrm{AlCl}_{3}$ ionic liquid density increased linearly with the $\mathrm{AlCl}_{3} / \mathrm{EMIC}$ ratio in the 1-1.7 range, in close agreement with literature reported results. ${ }^{20} \mathrm{~A}$ comparison between our experimental results and those calculated from literature was shown in Fig. S2† (temperature used for density calculation was $\left.25{ }^{\circ} \mathrm{C}\right) .{ }^{20} \mathrm{~A}$ significant difference between the two ionic liquids was that well behaved liquids for the Py13Cl- $\mathrm{AlCl}_{3}$ system could not form for $\mathrm{AlCl}_{3} / \mathrm{Py} 13 \mathrm{Cl}<1.4$, unlike the homogeneous clear liquids formed for $\mathrm{AlCl}_{3} / \mathrm{EMIC} \geq 1$. For the $\mathrm{Py} 13 \mathrm{Cl}-\mathrm{AlCl}_{3}$ system, a gel like mixture was formed with visible precipitates when $\mathrm{AlCl}_{3} / \mathrm{Py} 13 \mathrm{Cl}=1-1.3$. Also different was that for $\mathrm{AlCl}_{3} / \mathrm{Py} 13 \mathrm{Cl}$ $>1.3$, the change in density of $\mathrm{Py} 13 \mathrm{Cl}-\mathrm{AlCl}_{3}$ ionic liquid did not follow a linear trend with the increase in $\mathrm{AlCl}_{3} / \mathrm{Py} 13 \mathrm{Cl}$ molar ratio. Density decreased first from $\mathrm{AlCl}_{3} / \mathrm{Py} 13 \mathrm{Cl}=1.4$ to 1.5 and then increased as $\mathrm{AlCl}_{3} / \mathrm{Py} 13 \mathrm{Cl}$ further increased (Fig. 1b black curve).

We also measured viscosity of the two ionic liquid systems at temperature of 23 to $24{ }^{\circ} \mathrm{C}$. The viscosity of $\mathrm{Py} 13 \mathrm{Cl}-\mathrm{AlCl}_{3}$ ionic

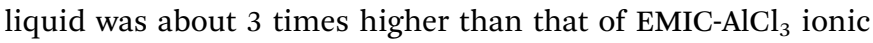
liquid (Fig. 1c), with its viscosity decreased as the $\mathrm{AlCl}_{3} / \mathrm{Py} 13 \mathrm{Cl}$ ratio changed from 1.4 to 1.6 and then slightly increased as the $\mathrm{AlCl}_{3}$ ratio further increased to 1.7. Conductivity measurements of these ionic liquids found that, corroborated with the higher viscosity of $\mathrm{Py} 13 \mathrm{Cl}-\mathrm{AlCl}_{3}$ ionic liquid, its ionic conductivity, measured at $25^{\circ} \mathrm{C}$, was about 3 times lower than that of EMIC$\mathrm{AlCl}_{3}$ (Fig. 1d). a

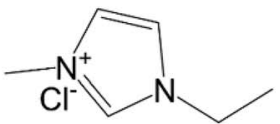

1-ethyl-3-methylimidazolium chloride

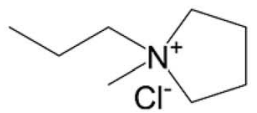

1-methyl-1-propylpyrrolidinium chloride





mole ratio of $\mathrm{AlCl}_{3}$ to organic chloride

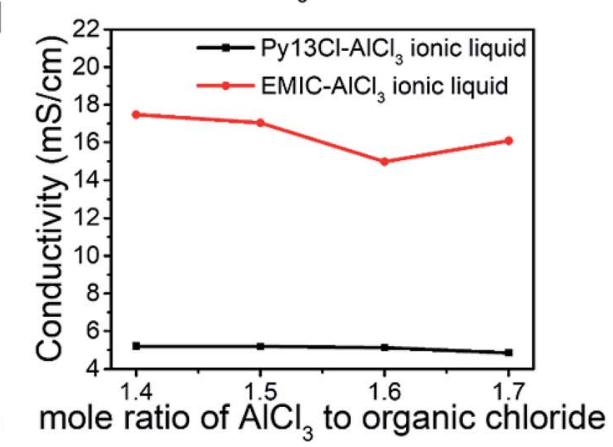

Fig. 1 Structures and physical properties of $\mathrm{Py} 13 \mathrm{Cl}-\mathrm{AlCl}_{3}$ and $\mathrm{EMIC}-\mathrm{AlCl}_{3}$ ionic liquid. (a) The structure of $\mathrm{EMIC}$ and $\mathrm{Py} 13 \mathrm{Cl}$, (b) density comparison between $\mathrm{Py} 13 \mathrm{Cl}-\mathrm{AlCl}_{3}$ and $\mathrm{EMIC}-\mathrm{AlCl}_{3}$, (c) viscosity comparison between $\mathrm{Py} 13 \mathrm{Cl}-\mathrm{AlCl}_{3}$ and $\mathrm{EMIC}-\mathrm{AlCl}_{3}$ measured at $23-24{ }^{\circ} \mathrm{C}$. (d) Conductivity comparison between $\mathrm{Py} 13 \mathrm{Cl}-\mathrm{AlCl}_{3}$ and $\mathrm{EMIC}-\mathrm{AlCl}_{3}$ measured at $25^{\circ} \mathrm{C}$. 


\section{Speciation of ionic liquids probed by Raman spectroscopy}

Fig. 2a and b showed the Raman spectra of EMIC- $\mathrm{AlCl}_{3}$ and $\mathrm{Py} 13 \mathrm{Cl}-\mathrm{AlCl}_{3}$ ionic liquids, respectively. A piece of $\mathrm{p}$-type boron doped silicon wafer was placed inside a clear plastic pouch containing the IL, and micro-Raman was done by focusing the laser through the clear plastic pouch onto the Si wafer surface to obtain spectra of both the Si and ILs within the laser focal volume. All spectra were taken when the silicon signal was maximized and all the peaks were then normalized to Si. The peaks at around $311 \mathrm{~cm}^{-1}$ and $433 \mathrm{~cm}^{-1}$ were known to belong to dimeric $\mathrm{Al}_{2} \mathrm{Cl}_{7}^{-}$, and the peak at around $350 \mathrm{~cm}^{-1}$ was assigned to monomeric $\mathrm{AlCl}_{4}^{-{ }^{-7,9,13,21,22}}$ The peak at around $520 \mathrm{~cm}^{-1}$ was the silicon wafer and normalized to 100 . Small peaks at around $240 \mathrm{~cm}^{-1}, 383 \mathrm{~cm}^{-1}, 597 \mathrm{~cm}^{-1}, 630 \mathrm{~cm}^{-1}$, $650 \mathrm{~cm}^{-1}, 700 \mathrm{~cm}^{-1}$ all belonged to the $\mathrm{EMI}^{+}$(Fig. 3). Some of them were also observed by Takahashi et al. and assigned to $\mathrm{EMI}^{+}$in their study of EMIC- $\mathrm{AlCl}_{3}$ ionic liquid. ${ }^{21}$ In addition, the Raman spectrum of pure EMIC solid was taken and compared with the 1.7 EMIC IL, and the result further confirmed the validity of this peak assignment (Fig. S3†). The peaks at
$311 \mathrm{~cm}^{-1}$ and $433 \mathrm{~cm}^{-1}$ increased in intensities and the peak at $350 \mathrm{~cm}^{-1}$ decreased in intensity as more $\mathrm{AlCl}_{3}$ was added, indicating that more $\mathrm{Al}_{2} \mathrm{Cl}_{7}{ }^{-}$and fewer $\mathrm{AlCl}_{4}{ }^{-}$were formed at higher $\mathrm{AlCl}_{3} / \mathrm{EMIC}$ or $\mathrm{AlCl}_{3} / \mathrm{Py} 13 \mathrm{Cl}$ ratios. The chemical equations govern these reactions were as follows: ${ }^{23-25}$

$$
\begin{gathered}
\mathrm{AlCl}_{3}+\mathrm{EMIC} \rightarrow \mathrm{EMI}^{+}+\mathrm{AlCl}_{4}^{-}\left(\mathrm{AlCl}_{3} \text { ratio } \leq 1\right) \\
\mathrm{AlCl}_{3}+\mathrm{Py} 13 \mathrm{Cl} \rightarrow \mathrm{Py} 13^{+}+\mathrm{AlCl}_{4}^{-}\left(\mathrm{AlCl}_{3} \text { ratio } \leq 1\right) \\
\mathrm{AlCl}_{3}+\mathrm{AlCl}_{4}^{-} \rightarrow \mathrm{Al}_{2} \mathrm{Cl}_{7}^{-}\left(1<\mathrm{AlC}_{3} \text { ratio }<2\right)
\end{gathered}
$$

Three peaks unique to the $\mathrm{Py} 13 \mathrm{Cl}-\mathrm{AlCl}_{3}$ ionic liquids were observed at $\sim 270 \mathrm{~cm}^{-1}, 377 \mathrm{~cm}^{-1}$ and $495 \mathrm{~cm}^{-1}$ (Fig. 3). These peaks were assigned to be neutral-like $\mathrm{AlCl}_{3}$ species in the form of aggregates, dimers, multimers and $\left(\mathrm{AlCl}_{3}\right)_{n}$ species. Peaks near $280 \mathrm{~cm}^{-1}$ were assigned to neutral aluminum chloride in the literature depending on the experimental conditions and chemical environment. ${ }^{26-28}$ The peak at $377 \mathrm{~cm}^{-1}$ was assigned to $\mathrm{Al}_{3} \mathrm{Cl}_{10}{ }^{-}$by Dymek et al. in their spectral study of $\mathrm{Al}_{3} \mathrm{Cl}_{10}{ }^{-}$, and



Fig. 2 Raman spectra of $\mathrm{Py} 13 \mathrm{Cl}-\mathrm{AlCl}_{3}$ and $\mathrm{EMIC}-\mathrm{AlCl}_{3}$ ionic liquid, normalized by the Si wafer peak at around $520 \mathrm{~cm}^{-1}$. (a) Raman spectra of $\mathrm{EMIC}-\mathrm{AlCl}_{3}$ at different $\mathrm{AlCl}_{3}$ ratios, with species assignment to major peaks, (b) Raman spectra of $\mathrm{Py} 13 \mathrm{Cl}-\mathrm{AlCl}_{3}$ ionic liquid at different $\mathrm{AlCl} 3$ ratio, with species assignment to major peaks. 
a

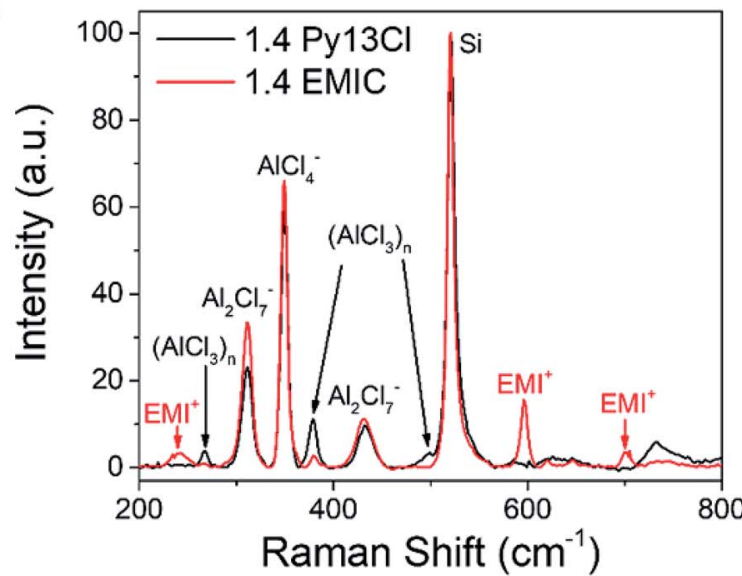

C

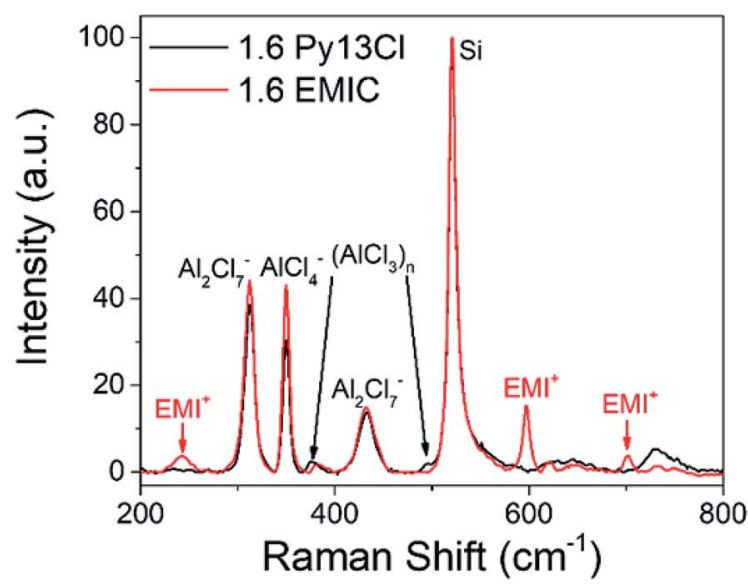

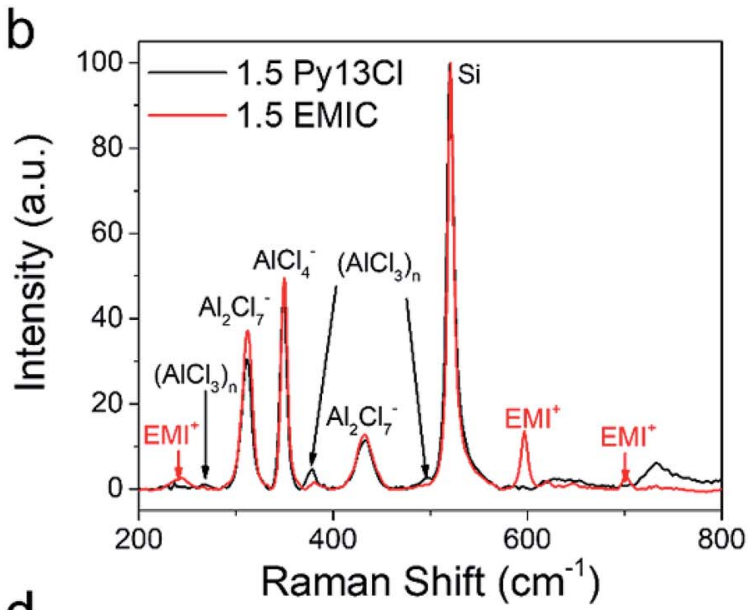

d

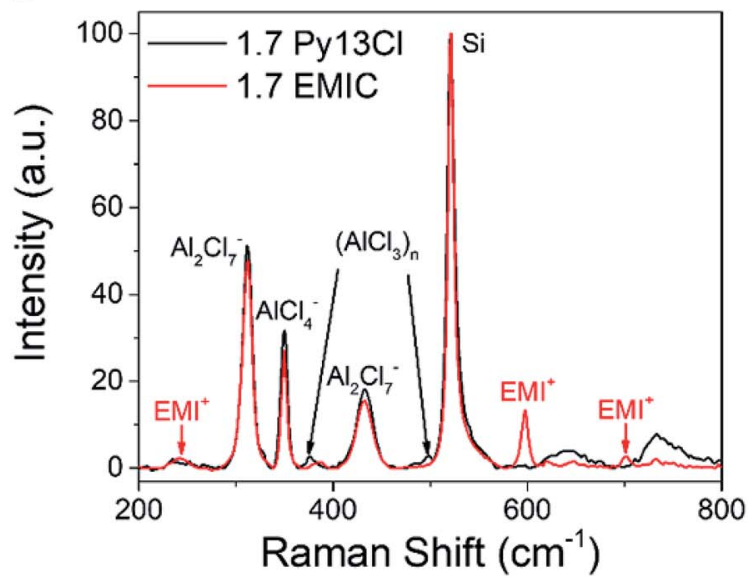

Fig. 3 Raman spectra comparison between $\mathrm{Py} 13 \mathrm{Cl}-\mathrm{AlCl}_{3}$ and $\mathrm{EMIC}-\mathrm{AlCl}_{3}$ ionic liquid. (a) $1.4 \mathrm{Py} 13 \mathrm{Cl}$ and $1.4 \mathrm{EMIC}$ comparison, (b) $1.5 \mathrm{Py} 13 \mathrm{Cl}$ and 1.5 EMIC comparison, (c) $1.6 \mathrm{Py} 13 \mathrm{Cl}$ and $1.6 \mathrm{EMIC}$ comparison, (d) $1.7 \mathrm{Py} 13 \mathrm{Cl}$ and $1.7 \mathrm{EMIC}$ comparison.

the shoulder peak at $495 \mathrm{~cm}^{-1}$ was also observed by Rytter $e t$ al. in their Raman spectroscopic investigation of the melts of $\mathrm{AlCl}_{3}$ and AlkCl (Alk $=\mathrm{Li}, \mathrm{K}, \mathrm{Cs}){ }^{26,29}$ Peak at $\sim 495 \mathrm{~cm}^{-1}$ was present when $\mathrm{AlCl}_{3}$ concentration exceeded $66.7 \mathrm{~mol} \%$ and the authors assigned it to higher polymeric $\mathrm{Al}_{x} \mathrm{Cl}_{3 x+1}{ }^{-}$ions, with the possibility of $x>3 .^{26}$ The peak position was also likely to shift depending on the cation size. ${ }^{26}$ These peaks were also observed in the inhomogeneous 1.3 Py13Cl- $\mathrm{AlCl}_{3}$ mixture.

\section{Quantitative speciation and 'ion percent' of electrolytes}

From Raman spectra, we estimated the concentrations of $\mathrm{AlCl}_{4}{ }^{-}$ and $\mathrm{Al}_{2} \mathrm{Cl}_{7}^{-}$in the ionic liquids by using the $\mathrm{Si}$ normalized Raman intensity of the peaks at $311 \mathrm{~cm}^{-1}\left(\mathrm{Al}_{2} \mathrm{Cl}_{7}^{-}\right)$and $350 \mathrm{~cm}^{-1}\left(\mathrm{AlCl}_{4}{ }^{-}\right)$respectively. In the $1.0 \mathrm{AlCl}_{3}: 1.0 \mathrm{EMIC}$ ionic liquid, the only species present were $\mathrm{AlCl}_{4}{ }^{-}$and $\mathrm{EMI}^{+}$, and the molar concentration of $\mathrm{AlCl}_{4}{ }^{-}$in the $1.0 \mathrm{IL}$ electrolyte equaled to that of $\mathrm{AlCl}_{3}$ (mole number of $\mathrm{AlCl}_{3}$ in the $\mathrm{IL} /$ molar volume of the IL). The concentration of $\mathrm{AlCl}_{4}{ }^{-}$at other $\mathrm{AlCl}_{3}$ ratios $(x)$ can be calculated using the following equation.

$$
\frac{\left[\mathrm{AlCl}_{4}{ }^{-}\right]_{1.0 \mathrm{EMIC}}}{I_{\mathrm{AlCl}_{4}{ }^{-}, 1.0 \mathrm{EMIC}}}=\frac{\left[\mathrm{AlCl}_{4}{ }^{-}\right]_{x \mathrm{EMIC}}}{I_{\mathrm{AlCl}_{4}{ }^{-}, x \mathrm{EMIC}}}
$$

In eqn $2, I$ was the intensity of the $\mathrm{AlCl}_{4}{ }^{-}$peak at $350 \mathrm{~cm}^{-1}$, and $x$ was the molar ratio of $\mathrm{AlCl}_{3} / \mathrm{EMIC}$ ranging from 1.1 to 1.7. The dimeric anion concentration was calculated by

$$
\frac{I_{\mathrm{Al}_{2} \mathrm{Cl}_{-}^{-}, x \mathrm{EMIC}}}{I_{\mathrm{AlCl}_{4}-}, x \mathrm{EMIC}}=0.78 \times \frac{\left[\mathrm{Al}_{2} \mathrm{Cl}_{7}^{-}\right], x \mathrm{EMIC}}{\left[\mathrm{AlCl}_{4}^{-}\right], x \mathrm{EMIC}}
$$

0.78 was the Raman cross section ratio between $\mathrm{Al}_{2} \mathrm{Cl}_{7}^{-}$and $\mathrm{AlCl}_{4}{ }^{-}$in the EMIC-AlCl ${ }_{3}$ ionic liquid, determined from the method described by Gilbert et al. ${ }^{30}$

For the Py13Cl- $\mathrm{AlCl}_{3}$ ILs, quantitative analysis of the speciation was not as straightforward due to the inability in forming a $\mathrm{AlCl}_{3} / \mathrm{Py} 13 \mathrm{Cl}=1.0$ ratio electrolyte. We analyzed the concentrations of $\mathrm{AlCl}_{4}{ }^{-}$and $\mathrm{Al}_{2} \mathrm{Cl}_{7}{ }^{-}$from their Raman peak intensities after normalizing the Raman spectra of the Py13Cl- $\mathrm{AlCl}_{3}$ and EMIC-AlCl ${ }_{3}$ electrolytes to the same Si reference placed into the two ionic liquids. By so doing we estimated the anions concentrations in the $\mathrm{Py} 13 \mathrm{Cl}$ electrolytes through the normalized Raman intensities using

$$
\frac{\left[\mathrm{AlCl}_{4}^{-}\right]_{y \mathrm{EMIC}}}{I_{\mathrm{AlCl}_{4}^{-}, y \mathrm{EMIC}}}=\frac{\left[\mathrm{AlCl}_{4}^{-}\right]_{y \mathrm{Py} 13 \mathrm{Cl}}}{I_{\mathrm{AlCl}_{4}^{-}, y \mathrm{Py} 13 \mathrm{Cl}}}
$$




$$
\frac{\left[\mathrm{Al}_{2} \mathrm{Cl}_{7}^{-}\right]_{y \mathrm{EMIC}}}{I_{\mathrm{Al}_{2} \mathrm{Cl}_{7}{ }^{-}, y \mathrm{EMIC}}}=\frac{\left[\mathrm{Al}_{2} \mathrm{Cl}_{7}^{-}\right]_{y \mathrm{Py} 13 \mathrm{Cl}}}{I_{\mathrm{Al}_{2} \mathrm{Cl}_{7}{ }^{-}, y \mathrm{Py} 13 \mathrm{Cl}}}
$$

In eqn (4) and (5), $I$ was the normalized intensity for $\mathrm{AlCl}_{4}{ }^{-}$ and $\mathrm{Al}_{2} \mathrm{Cl}_{7}^{-}$and $y$ was the ratio of $\mathrm{AlCl}_{3}$ ranging from 1.4 to 1.7.

The ratios between $\left[\mathrm{Al}_{2} \mathrm{Cl}_{7}^{-}\right]$to $\left[\mathrm{AlCl}_{4}{ }^{-}\right]$were similar in both $\mathrm{Py} 13 \mathrm{Cl}-\mathrm{AlCl}_{3}$ and $\mathrm{EMIC}-\mathrm{AlCl}_{3}$ ionic liquids, especially at $\mathrm{AlCl}_{3} /$ organic chloride $=1.4-1.6$ (Fig. 4a). In both systems, the monomeric anion concentration decreased with increasing $\mathrm{AlCl}_{3}$ ratio, and was lower in the $\mathrm{Py} 13 \mathrm{Cl}-\mathrm{AlCl}_{3}$ system than that in $\mathrm{EMIC}^{-\mathrm{AlCl}_{3}}$ at $\mathrm{AlCl}_{3}$ ratio equals to 1.4-1.6. When $\mathrm{AlCl}_{3}$ / organic chloride $=1.7$, the monomer anion concentration in both ionic liquids was similar (Fig. 4b). As expected, the $\mathrm{Al}_{2} \mathrm{Cl}_{7}{ }^{-}$ concentration increased as the $\mathrm{AlCl}_{3}$ ratio increased (Fig. 4c), and was always lower in the $\mathrm{Py} 13 \mathrm{Cl}-\mathrm{AlCl}_{3}$ IL than in the EMIC$\mathrm{AlCl}_{3} \mathrm{IL}$ (Fig. 4c). This made the overall concentrations of $\mathrm{AlCl}_{4}{ }^{-}$ and $\mathrm{Al}_{2} \mathrm{Cl}_{7}^{-}$lower in the $\mathrm{Py} 13 \mathrm{Cl}-\mathrm{AlCl}_{3}$ IL than that in the EMIC$\mathrm{AlCl}_{3} \mathrm{IL}$ at a given $\mathrm{AlCl}_{3}$ to organic chloride ratio (Fig. 4b and c).

We defined a term "ion percent" as the ratio between $\left[\mathrm{AlCl}_{4}{ }^{-}\right]$ $+2 \times\left[\mathrm{Al}_{2} \mathrm{Cl}_{7}{ }^{-}\right]$and $\left[\mathrm{AlCl}_{3}\right]$. By so doing we only included $\left[\mathrm{AlCl}_{4}{ }^{-}\right]$ and $\left[\mathrm{Al}_{2} \mathrm{Cl}_{7}^{-}\right]$since they were the only electrochemically active species in our ILs for Al battery operation. If the ion percent was 1 , it indicated that all $\mathrm{AlCl}_{3}$ were consumed for making monomers and dimers. When the ion percent was less than 1, larger $\left(\mathrm{AlCl}_{3}\right)_{n}$ could form. For EMIC-AlCl $3 \mathrm{IL}$, the ion percent values were near 1.0 (Fig. 4d), suggesting anions in the electrolytes were mostly in the form of $\mathrm{AlCl}_{4}{ }^{-}$and $\mathrm{Al}_{2} \mathrm{Cl}_{7}{ }^{-}$. In the Py13Cl$\mathrm{AlCl}_{3}$ system, however, this ion percent value was always lower. When the $\mathrm{AlCl}_{3}$ ratio to $\mathrm{Py} 13 \mathrm{Cl}$ was 1.4 (the lowest required to form a liquid), the ion percent was at its lowest, 0.85, and increased slightly as more $\mathrm{AlCl}_{3}$ was added and was always lower than 1 . This trend in ion percent was consistent with the observations of the three unique peaks $\left(270 \mathrm{~cm}^{-1}, 377 \mathrm{~cm}^{-1}\right.$, $495 \mathrm{~cm}^{-1}$ ) in the $\mathrm{Py} 13 \mathrm{Cl}-\mathrm{AlCl}_{3}$ Raman spectra. As the $\mathrm{AlCl}_{3}$ content increased, all these peaks had their intensities decreased, with the peaks at $270 \mathrm{~cm}^{-1}$ and $377 \mathrm{~cm}^{-1}$ being the most obvious. This trend suggested reduced concentrations of $\left(\mathrm{AlCl}_{3}\right)_{n}$ species as $\mathrm{AlCl}_{3} / \mathrm{Py} 13 \mathrm{Cl}$ increased, which was also reflected by the slight increase in ion percent for the $\mathrm{Py} 13 \mathrm{Cl}-\mathrm{AlCl}_{3}$ IL. In the EMIC-AlCl $\mathrm{Al}_{3}$ spectra, however, these three peaks were absent, which was consistent with its ion percent value always close to 1 . The error bars in Fig. 4 were obtained using formulas from error propagation (eqn $\mathrm{S} 1 \dagger$ ).

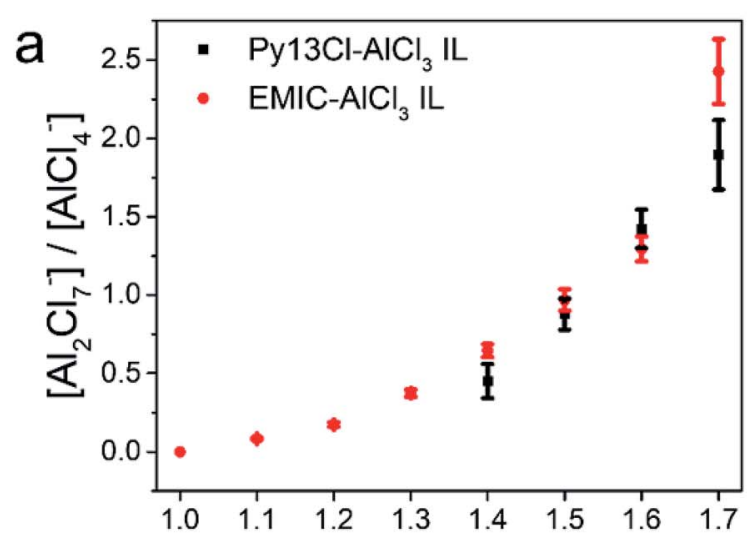

mole ratio of $\mathrm{AlCl}_{3}$ to organic chloride

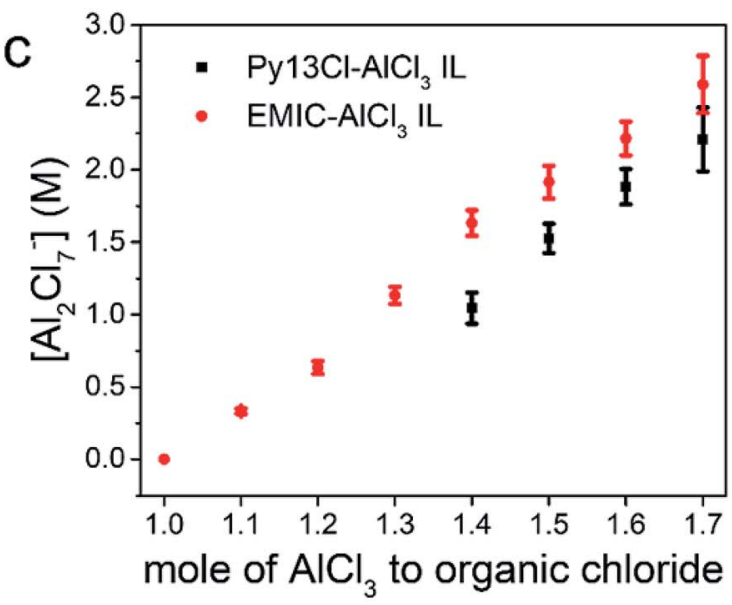

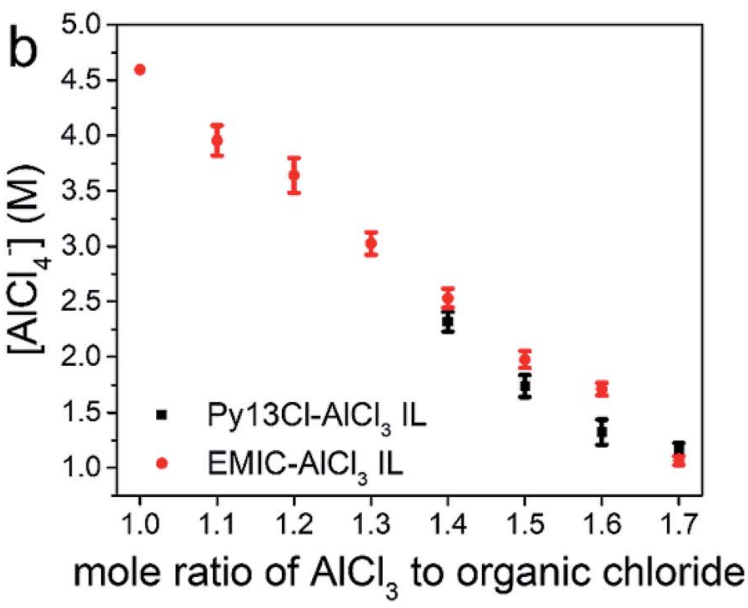

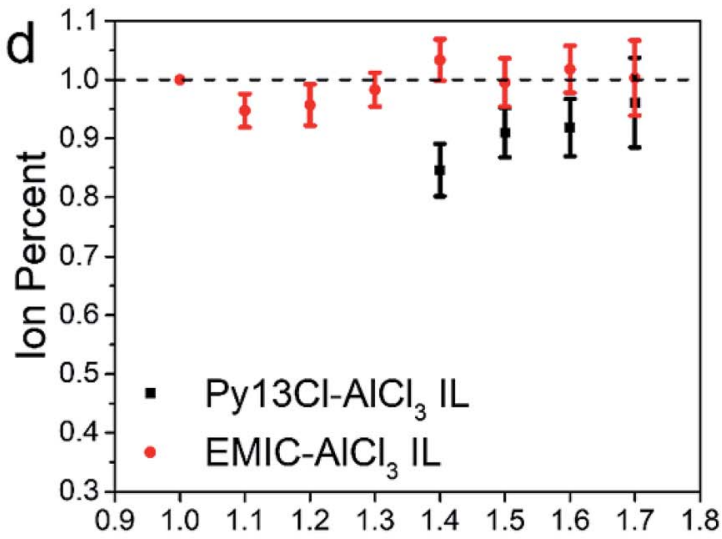

mole ratio of $\mathrm{AlCl}_{3}$ to organic chloride

Fig. 4 Species concentrations and ion percent comparison between $\mathrm{Py} 13 \mathrm{Cl}-\mathrm{AlCl}_{3}$ and $\mathrm{EMIC}-\mathrm{AlCl}_{3}$ ionic liquids (a) [Dimer] to [Monomer] ratios comparison between these two ionic liquids, (b) monomer concentration comparison between these two ionic liquids, (c) dimer concentration comparison between these two ionic liquids, (d) ion percent comparison between these two ionic liquids. 


\section{Cyclic voltammetry and battery data}

The $\mathrm{Py} 13 \mathrm{Cl}-\mathrm{AlCl}_{3}$ ionic liquid was used as an electrolyte for rechargeable aluminum-graphite battery (Fig. 5a). A simplistic battery operation mechanism was that during charging, $\mathrm{AlCl}_{4}{ }^{-}$ in the electrolyte intercalated into the positive electrode and oxidized the graphite, making $\mathrm{C}_{n}\left(\mathrm{AlCl}_{4}{ }^{-}\right)$compound with electrons released. At the negative electrode, $\mathrm{Al}_{2} \mathrm{Cl}_{7}{ }^{-}$in the electrolyte was reduced to $\mathrm{Al}$ metal and formed $\mathrm{AlCl}_{4}{ }^{-}$that migrated to the positive electrode side. ${ }^{7,9}$ When the battery was discharged, the opposite reactions occurred. At the negative electrode, aluminum metal was oxidized to $\mathrm{Al}_{2} \mathrm{Cl}_{7}^{-}$by consuming $\mathrm{AlCl}_{4}{ }^{-}$in the electrolyte. At the positive electrode, $\mathrm{AlCl}_{4}{ }^{-}$deintercalated from the graphite and reduced $\mathrm{C}_{n}\left(\mathrm{AlCl}_{4}{ }^{-}\right)$ to $\mathrm{C}_{n}$.

Cyclic voltammetry of the graphite electrodes (Fig. 5b) and aluminum electrode (Fig. $5 \mathrm{c}$ ) in $\mathrm{Al}$ batteries were performed in $1.5 \mathrm{AlCl}_{3}: 1.0$ EMIC and $1.5 \mathrm{AlCl}_{3}: 1.0 \mathrm{Py} 13 \mathrm{Cl}$ electrolytes respectively (scan rate $=0.58 \mathrm{mV} \mathrm{s}^{-1}$ with an $\mathrm{Al}$ metal reference electrode). The overall shapes of these two curves were somewhat similar, but obvious difference was observed. The 1.5 $\mathrm{AlCl}_{3} / \mathrm{Py} 13 \mathrm{Cl}$ electrolyte showed a slightly higher voltage


Fig. 5 Aluminum-graphite battery performances when $\mathrm{Py} 13 \mathrm{Cl}-\mathrm{AlCl}_{3}$ and $\mathrm{EMIC}-\mathrm{AlCl}_{3}$ ionic liquids were used as electrolyte (a) schematic depiction of how the Al-graphite battery worked, (b) cyclic voltammetry data at graphite electrode, three electrodes CV with $\mathrm{Al}$ as reference, (c) cyclic voltammetry data at Al electrode, three electrodes CV with Al as reference, (d) stability and capacity of Al-graphite batteries using 1.5 $\mathrm{Py} 13 \mathrm{Cl}$ and 1.5 EMIC as electrolyte (C-rate were indicated in the figure. For 1.5 Py13Cl battery, cycle 1-10: cutoff voltage 2.6 V, cycle 11-55: cutoff voltage $2.5 \mathrm{~V}$, cycle 56-100: cutoff voltage $2.4 \mathrm{~V}$. For 1.5 EMIC battery, cutoff voltage was $2.4 \mathrm{~V}$ for all cycles), (e) Al battery charge-discharge curves comparison between $1.5 \mathrm{Py} 13 \mathrm{Cl}$ and $1.5 \mathrm{EMIC}$ as electrolytes. 
window. The irreversible reaction did not appear until a potential of $2.6 \mathrm{~V}$, whereas in the $1.5 \mathrm{AlCl}_{3} / \mathrm{EMIC}$ electrolyte the irreversible reaction appeared at $2.4 \mathrm{~V}$. The overpotential (voltage difference in redox peaks) in the Py13Cl based electrolyte was higher than that in the EMIC based electrolyte, attributed to higher parasitic resistance due to the higher viscosity and lower conductivity of the $\mathrm{Py} 13 \mathrm{Cl}$ system. The graphite side CVs had current normalized because the graphite electrodes loading for the two CVs were too low to keep the mass exact (Experimental methods section). Aluminum redox was clearly observed in both systems (Fig. 5c). It was observed that at the same voltage, the 1.5 EMIC battery showed higher current density than those in $1.5 \mathrm{Py} 13 \mathrm{Cl}$ battery, suggesting more facile $\mathrm{Al}$ redox reaction in the EMIC based electrolyte. The aluminum side CVs didn't need normalization as the size of the aluminum electrodes in the two CVs were kept the same (Experimental methods section).

The aluminum-graphite battery using $1.5 \mathrm{AlCl}_{3}: 1.0 \mathrm{Py} 13 \mathrm{Cl}$ as electrolyte showed activation behavior during initial cycling (Fig. 5d), after which clear discharge voltage plateaus at around $\sim 2.2 \mathrm{~V}$ and $\sim 1.8 \mathrm{~V}$ appeared (Fig. 5e black curve). The battery was then cycled at various current densities $\left(100 \mathrm{~mA} \mathrm{~g}^{-1}\right.$ to $800 \mathrm{~mA} \mathrm{~g}^{-1}$ ) to investigate the rate performance, with high coulombic efficiency in the range of $99 \%$ to $100 \%$. The battery at $100 \mathrm{~mA} \mathrm{~g}^{-1}$ current under a cutoff voltage of $2.4 \mathrm{~V}$ showed


about $99.2 \%$. The discharging energy could be maintained at around $141 \mathrm{~mW} \mathrm{~h} \mathrm{~g}^{-1}$ (based on the graphite mass) with an energy efficiency about $\sim 89 \%$. The aluminum-graphite battery using $1.5 \mathrm{AlCl}_{3}$ : 1.0 EMIC as electrolyte could operate from $1 \mathrm{~V}$ to $2.4 \mathrm{~V}$ and no activation was needed in the beginning. Both batteries had similar stability over 100 cycles of chargedischarge (Fig. 5d). Comparison of the charge-discharge curves between $1.5 \mathrm{Py} 13 \mathrm{Cl}$ and 1.5 EMIC batteries at a current density of $100 \mathrm{~mA} \mathrm{~g}^{-1}$ (Fig. 5e) showed a larger overpotential in the 1.5 Py $13 \mathrm{Cl}$ based battery, consistent with the cyclic voltammetry data (Fig. 5b).

\section{Discussion}

In this work, we investigated a new ionic liquid system based on $\mathrm{Py} 13 \mathrm{Cl}$ and $\mathrm{AlCl}_{3}$ for rechargeable $\mathrm{Al}$ batteries. Although the battery performance failed to match that based on the commonly used EMIC and $\mathrm{AlCl}_{3}$ IL. The results led to fundamental insights into electrolyte composition, chemical and physical properties and their relation to battery performance.

We used Raman spectroscopy as a tool to probe and quantify chloroaluminate anionic species in different ionic liquids. In the EMIC-AlCl ${ }_{3}$ ILs, the peak at around $598 \mathrm{~cm}^{-1}$ assigned to be $\mathrm{EMI}^{+}$was present in every spectrum. Therefore, besides the $\mathrm{Si}$ chip peak at around $520 \mathrm{~cm}^{-1}$, the $\mathrm{EMI}^{+}$peak was also useful as an internal normalization factor to calculate $\mathrm{AlCl}_{4}{ }^{-}$and $\mathrm{Al}_{2} \mathrm{Cl}_{7}{ }^{-}$

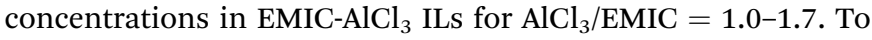
this end, we first determined the concentration of $\mathrm{EMI}^{+}$in every ratio of $\mathrm{AlCl}_{3}$ by the following equation.

$$
\left[\mathrm{EMI}^{+}\right]_{x \mathrm{EMIC}}=\frac{1}{V_{n, x \mathrm{EMIC}}}
$$

In eqn (6), $x$ was the $\mathrm{AlCl}_{3}$ to EMIC ratio ranging from 1.0 to 1.7 , and $V_{n}$ was the molar volume of the IL, which could be determined from the average molecular weight dividing by the measured density. The $\mathrm{EMI}^{+}$concentrations in different $\mathrm{AlCl}_{3}$ ratio ILs were different due to their difference in molar volume, originated from their difference in densities (Fig. 1b).

Next, the $\mathrm{AlCl}_{4}{ }^{-}$and $\mathrm{Al}_{2} \mathrm{Cl}_{7}{ }^{-}$intensity, normalized to $\mathrm{EMI}^{+}$, were calculated using the following equations.

$$
\begin{gathered}
I_{\mathrm{AlCl}_{4}{ }^{-}, x}=\frac{I_{\mathrm{AlCl}_{4}^{-}, \text {raw }, x}}{I_{\mathrm{EMI}^{+}, \text {raw }, x}} \times \frac{\left[\mathrm{EMI}^{+}\right]_{x \mathrm{EMIC}}}{\left[\mathrm{EMI}^{+}\right]_{1.0 \mathrm{EMIC}}} \\
I_{\mathrm{Al}_{2} \mathrm{Cl}_{7}{ }^{-}, x}=\frac{I_{\mathrm{Al}_{2} \mathrm{Cl}_{7}{ }^{-}, \text {raw }, x}}{I_{\mathrm{EMI}^{+}, \text {raw }, x}} \times \frac{\left[\mathrm{EMI}^{+}\right]_{x \mathrm{EMIC}}}{\left[\mathrm{EMI}^{+}\right]_{1.0 \mathrm{EMIC}}}
\end{gathered}
$$

In eqn (7) and (8), subscript $x$ was the ratio of $\mathrm{AlCl}_{3}$ to EMIC ranging from 1.0 to 1.7. $I_{\mathrm{AlCl}_{4}^{-}, x}$ and $I_{\mathrm{Al}_{2} \mathrm{Cl}_{7}^{-}, x}$ were the $\mathrm{EMI}^{+}$ normalized intensity for $\mathrm{AlCl}_{4}{ }^{-}$and $\mathrm{Al}_{2} \mathrm{Cl}_{7}{ }^{-}$in $x \mathrm{EMIC}$, respectively. $I_{\mathrm{AlCl}_{4}{ }^{-}, \text {raw }, x}, I_{\mathrm{Al}_{2} \mathrm{Cl}_{7}{ }^{-}, \text {raw }, x}$, and $I_{\mathrm{EMI}^{+} \text {,raw }, x}$ were the raw Raman intensity of $\mathrm{AlCl}_{4}{ }^{-}, \mathrm{Al}_{2} \mathrm{Cl}_{7}^{-}$and $\mathrm{EMI}^{+}$in $x \mathrm{EMIC}$. Lastly, $\left[\mathrm{EMI}^{+}\right]_{x \mathrm{EMIC}}$ and $\left[\mathrm{EMI}^{+}\right]_{1.0 \mathrm{EMIC}}$ were the $\mathrm{EMI}^{+}$concentration in $x$ EMIC and 1.0 EMIC, calculated from eqn (6), respectively. The ratio of $\frac{\left[\mathrm{EMI}^{+}\right]_{x \mathrm{EMIC}}}{\left[\mathrm{EMI}^{+}\right]_{1.0 \mathrm{EMIC}}}$ was a correction factor for the $\mathrm{EMI}^{+}$ normalized intensity, due to the fact that $\mathrm{EMI}^{+}$concentration were different in different $\mathrm{AlCl}_{3}$ ratio ILs.

After obtaining the $\mathrm{EMI}^{+}$normalized peak intensity for $\mathrm{AlCl}_{4}{ }^{-}$ and $\mathrm{Al}_{2} \mathrm{Cl}_{7}{ }^{-}$from eqn (7) and (8), these two quantities were plugged into eqn (2) and (3) to determine the $\mathrm{AlCl}_{4}{ }^{-}$and $\mathrm{Al}_{2} \mathrm{Cl}_{7}{ }^{-}$concentrations, similar to the $\mathrm{Si}$ normalization case. Ion percent could also be easily calculated using these newly obtained $\mathrm{AlCl}_{4}{ }^{-}$and $\mathrm{Al}_{2} \mathrm{Cl}_{7}^{-}$concentrations. These results obtained by $\mathrm{EMI}^{+}$normalization were compared with the Si normalization results (Fig. S4 $\dagger$ ), showing a high degree of agreement. This confirmed that the validity of the normalization method using $\mathrm{Si}$ as an external Raman reference. We believe that this method could be broadly applicable to facilitate quantitative anion speciation comparisons of a wide range ILs that lack a common cation Raman signature.

The Py13Cl-AlCl 3 ionic liquids exhibited different properties (higher viscosity, lower conductivity, lower overall monomeric and dimeric anion concentrations and formation of large $\left(\mathrm{AlCl}_{3}\right)_{n}$

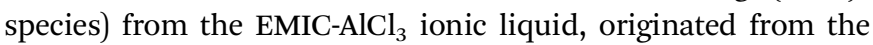
larger cationic size of $\mathrm{Py}_{13}{ }^{+}$than the $\mathrm{EMI}^{+}$cation (DFT calculated size of the $\mathrm{Py}^{+} 3^{+}$and $\mathrm{EMI}^{+} \sim 142 \AA^{3}$ and $118 \AA^{3}$, respectively, Fig. $\mathrm{S} 1 \dagger) .{ }^{31}$ When the cation size changed in an ionic liquid, it could greatly affect the chemical environment around it and its solvation shell. Bigger size cations could stabilize and favored the formation of larger species such as $\left(\mathrm{AlCl}_{3}\right)_{n}$. In addition, the pisystem and the Brønsted acidic set of hydrogen atoms, which were unique in the $\mathrm{EMI}^{+}$and absent in the $\mathrm{Py} 13^{+}$, helped with solubilizing and liquidizing of the ionic liquid. Larger $\left(\mathrm{AlCl}_{3}\right)_{n}$ species tend to form in the $\mathrm{Py} 13 \mathrm{Cl}-\mathrm{AlCl}_{3}$ system without forming a stable solvation shell. ${ }^{32}$ This trend was reported by several authors in the literature. ${ }^{26,29}$ Larger $\left(\mathrm{AlCl}_{3}\right)_{n}$ species were only observed in $\mathrm{Py} 13 \mathrm{Cl}-\mathrm{AlCl}_{3}$ ionic liquid, and their concentration decreased as we increased the $\mathrm{AlCl}_{3}$ concentration. 
We also calculated the interaction energy and the Gibbs free energy change for de-solvation in these two ILs (Table S1 $\dagger$ ). Our results showed that the interactions between $\mathrm{EMI}^{+}$and $\mathrm{AlCl}_{4}{ }^{-}$ was always stronger than that between $\mathrm{Py}_{13}{ }^{+}$and $\mathrm{AlCl}_{4}{ }^{-}$. Weaker interaction in the $\mathrm{Py} 13 \mathrm{Cl}-\mathrm{AlCl}_{3}$ electrolyte was mainly due to the larger size of Py $13^{+}$, which decreased its effective positive charge and weakened its electrostatic interactions with $\mathrm{AlCl}_{4}{ }^{-}$. With a smaller interaction energy between $\mathrm{Py} 13^{+}$and $\mathrm{AlCl}_{4}{ }^{-}$, the equilibrium constant for eqn (1b), compared to eqn (1a), would be smaller. As a result, larger polymeric $\left(\mathrm{AlCl}_{3}\right)_{n}$ species were present in some of the lower ratios Py13Cl IL. Once enough $\mathrm{AlCl}_{3}$ was introduced to the system, the total number of ions in the IL increased and these polymeric species started to disappear, as suggested by the diminishing of the Raman peak at $270 \mathrm{~cm}^{-1}$ (Fig. 3). In addition, unlike the homogeneous $\mathrm{AlCl}_{3} /$ $\mathrm{EMIC}=1$ ionic liquid, this weaker electrostatic interaction made the formation of stable solvation shell in Py13Cl IL more difficult, which led to the inability of forming an IL for $\mathrm{AlCl}_{3}$ / $\mathrm{Py} 13 \mathrm{Cl}=1$. This phenomenon also suggested mismatch of cation and anion sizes at the cation/anion ratio $=1$ condition to keep charge-neutrality while forming stable solvation shells with the same coordination numbers with counter-ion as in the $\mathrm{AlCl}_{3}$-EMIC case. When larger dimeric ions increased in concentration above a threshold level for $\mathrm{AlCl}_{3} / \mathrm{Py} 13 \mathrm{Cl} \geq 1.4$ electrolytes, the system evolves into a well solvated liquid.

The Py13Cl- $\mathrm{AlCl}_{3}$ contained large species and lower overall concentrations of dimeric and monomeric anions. This combined with the larger size cations in the electrolyte afforded ILs exhibiting greater viscosity and lower ionic conductivity than the EMIC counterparts. This led to a larger overpotential for battery charge and discharge, giving lower energy and voltage efficiency as observed. In addition, the lower conductivity of this electrolyte also limited the current at the negative electrode, at which aluminum redox happened (Fig. 5c). Even though the cations in our electrolytes did not directly participate in any actual electrochemical reaction, they could affect the performance of the battery by controlling the anionic species around it, which in turn affected the physical properties of the IL including viscosity and conductivity. From our results, smaller cations could have positive effects on the battery, by decreasing the viscosity and increasing the conductivity of the resulting electrolyte. This could provide a guide to the synthesis of new ionic liquids for optimized batteries in the future.

\section{Conclusion}

In this work, new ionic liquids were formed by mixing various ratios of $\mathrm{AlCl}_{3}$ with $\mathrm{Py} 13 \mathrm{Cl}$. The physical and chemical properties of resulting ionic liquid were investigated and they turned out to be very different from the commonly used EMIC- $\mathrm{AlCl}_{3}$ ionic liquid. At the same $\mathrm{AlCl}_{3}$ /organic chloride ratio, $\mathrm{Py} 13 \mathrm{Cl}-$ $\mathrm{AlCl}_{3}$ system had lower density, higher viscosity and lower conductivity than the $\mathrm{EMIC}^{-\mathrm{AlCl}_{3}}$ counterpart. Clear liquid could not form in Py13Cl- $\mathrm{AlCl}_{3} \mathrm{IL}$ until $\mathrm{AlCl}_{3} / \mathrm{Py} 13 \mathrm{Cl}$ molar ratio reached 1.4. Raman spectroscopy revealed monomeric $\mathrm{AlCl}_{4}{ }^{-}$ and dimeric $\mathrm{Al}_{2} \mathrm{Cl}_{7}{ }^{-}$existed in both ILs, with their concentrations decreased and increased, respectively, as the content of
$\mathrm{AlCl}_{3}$ was increased. The sum of $\left[\mathrm{AlCl}_{4}{ }^{-}\right]$and $\left[\mathrm{Al}_{2} \mathrm{Cl}_{7}{ }^{-}\right]$was lower in the Py13Cl- $\mathrm{AlCl}_{3} \mathrm{IL}$, in agreement with its lower conductivity. Large polymeric $\left(\mathrm{AlCl}_{3}\right)_{n}$ species only existed in $\mathrm{Py} 13 \mathrm{Cl}-\mathrm{AlCl}_{3} \mathrm{IL}$. The properties for both ionic liquids as electrolytes in an aluminum-graphite battery were also compared. The batteries had similar capacity and similar stability. However, the battery with $\mathrm{Py} 13 \mathrm{Cl}-\mathrm{AlCl}_{3}$ as electrolyte had higher overpotential, which was due to its higher viscosity and lower conductivity. The cation/anion size in an IL can dictate its physical properties including density, viscosity and conductivity, and the battery performances such as overpotential, rate capabilities and energy efficiency. All of these are rooted in the solvation and coordination of ion-counter ions in the ionic liquid. Therefore, in order to synthesize better ionic liquids to be used as electrolyte, the cation size needs to be controlled carefully. Overall, RTILs are still very open for further investigation. With more and more discoveries and understanding on RTILs, their advantageous properties, including low flammability and high rate capabilities can be further utilized in energy storage.

\section{Conflicts of interest}

There are no conflicts to declare.

\section{Acknowledgements}

This work is supported by the US Department of Energy DOE DE-SC0016165, a Bits and Watts Fellowship from the Stanford Precourt Institute of Energy, the Global Networking Talent 3.0 plan (NTUST 104DI005) from the Ministry of Education of Taiwan, and the Taishan Scholar Project for Young Scholars of Shandong Province of China. P. K. and A. J. A. gratefully acknowledge the High-Performance Computing facilities of the Freie Universität Berlin (ZEDAT) for computational time.

\section{References}

1 J. Jorné, J. T. Kim and D. Kralik, The zinc-chlorine battery: half-cell overpotential measurements, J. Appl. Electrochem., 1979, 9(5), 573-579.

2 G. A. Giffin, Ionic liquid-based electrolytes for "beyond lithium" battery technologies, J. Mater. Chem. A, 2016, 4(35), 13378-13389.

3 A. Abouimrane, D. Dambournet, K. W. Chapman, P. J. Chupas, W. Weng and K. Amine, A New Class of Lithium and Sodium Rechargeable Batteries Based on Selenium and Selenium-Sulfur as a Positive Electrode, $J$. Am. Chem. Soc., 2012, 134(10), 4505-4508.

4 S. Xin, Y.-X. Yin, Y.-G. Guo and L.-J. Wan, A High-Energy Room-Temperature Sodium-Sulfur Battery, Adv. Mater., 2014, 26(8), 1261-1265.

5 P. Meister, O. Fromm, S. Rothermel, J. Kasnatscheew, M. Winter and T. Placke, Sodium-Based vs. Lithium-Based Dual-Ion Cells: Electrochemical Study of Anion Intercalation/De-Intercalation into/from Graphite and Metal Plating/Dissolution Behavior, Electrochim. Acta, 2017, 228, 18-27. 
6 L. C. Merrill and J. L. Schaefer, Electrochemical Properties and Speciation in $\mathrm{Mg}$ (HMDS)2-Based Electrolytes for Magnesium Batteries as a Function of Ethereal Solvent Type and Temperature, Langmuir, 2017, 33(37), 9426-9433.

7 M.-C. Lin, M. Gong, B. Lu, Y. Wu, D.-Y. Wang, M. Guan, M. Angell, C. Chen, J. Yang, B.-J. Hwang and H. Dai, An ultrafast rechargeable aluminium-ion battery, Nature, 2015, 520(7547), 324-328.

8 D.-Y. Wang, C.-Y. Wei, M.-C. Lin, C.-J. Pan, H.-L. Chou, H.-A. Chen, M. Gong, Y. Wu, C. Yuan, M. Angell, Y.-J. Hsieh, Y.-H. Chen, C.-Y. Wen, C.-W. Chen, B.-J. Hwang, C.-C. Chen and H. Dai, Advanced rechargeable aluminium ion battery with a high-quality natural graphite cathode, Nat. Commun., 2017, 8, 14283.

9 M. Angell, C.-J. Pan, Y. Rong, C. Yuan, M.-C. Lin, B.-J. Hwang and H. Dai, High Coulombic efficiency aluminum-ion battery using an $\mathrm{AlCl}_{3}$-urea ionic liquid analog electrolyte, Proc. Natl. Acad. Sci. U. S. A., 2017, 114(5), 834-839.

$10 \mathrm{C}$. Ru and B. Konig, Low melting mixtures in organic synthesis - an alternative to ionic liquids?, Green Chem., 2012, 14(11), 2969-2982.

11 M. S. Sitze, E. R. Schreiter, E. V. Patterson and R. G. Freeman, Ionic Liquids Based on $\mathrm{FeCl}_{3}$ and $\mathrm{FeCl}_{2}$. Raman Scattering and Ab Initio Calculations, Inorg. Chem., 2001, 40(10), 2298-2304.

12 J.-K. Kim, A. Matic, J.-H. Ahn and P. Jacobsson, An imidazolium based ionic liquid electrolyte for lithium batteries, J. Power Sources, 2010, 195(22), 7639-7643.

13 P. Eiden, Q. Liu, S. Zein El Abedin, F. Endres and I. Krossing, An Experimental and Theoretical Study of the Aluminium Species Present in Mixtures of $\mathrm{AlCl}_{3}$ with the Ionic Liquids [BMP]Tf2N and [EMIm]Tf2N, Chem. -Eur. J., 2009, 15(14), 3426-3434.

14 T. Hosokawa, K. Matsumoto, T. Nohira, R. Hagiwara, A. Fukunaga, S. Sakai and K. Nitta, Stability of Ionic Liquids against Sodium Metal: A Comparative Study of 1Ethyl-3-methylimidazolium Ionic Liquids with Bis(fluorosulfonyl)amide and Bis(trifluoromethylsulfonyl) amide, J. Phys. Chem. C, 2016, 120(18), 9628-9636.

15 X. Qi, B. Blizanac, A. DuPasquier, P. Meister, T. Placke, M. Oljaca, J. Li and M. Winter, Investigation of PF6- and TFSI-anion intercalation into graphitized carbon blacks and its influence on high voltage lithium ion batteries, Phys. Chem. Chem. Phys., 2014, 16(46), 25306-25313.

16 S. Rothermel, P. Meister, G. Schmuelling, O. Fromm, H.-W. Meyer, S. Nowak, M. Winter and T. Placke, Dualgraphite cells based on the reversible intercalation of bis(trifluoromethanesulfonyl)imide anions from an ionic liquid electrolyte, Energy Environ. Sci., 2014, 7(10), 3412-3423.

17 X. Zhang, Y. Tang, F. Zhang and C.-S. Lee, A Novel Aluminum-Graphite Dual-Ion Battery, Adv. Energy Mater., 2016, 6(11), 1502588.

18 N. Jayaprakash, S. K. Das and L. A. Archer, The rechargeable aluminum-ion battery, Chem. Commun., 2011, 47(47), 1261012612.

19 Y. Wu, M. Gong, M.-C. Lin, C. Yuan, M. Angell, L. Huang, D.-Y. Wang, X. Zhang, J. Yang, B.-J. Hwang and H. Dai, 3D
Graphitic Foams Derived from Chloroaluminate Anion Intercalation for Ultrafast Aluminum-Ion Battery, Adv. Mater., 2016, 28(41), 9218-9222.

20 A. A. Fannin, D. A. Floreani, L. A. King, J. S. Landers, B. J. Piersma, D. J. Stech, R. L. Vaughn, J. S. Wilkes and J. L. Williams, Properties of 1,3-dialkylimidazolium chloride-aluminum chloride ionic liquids. 2. Phase transitions, densities, electrical conductivities, and viscosities, J. Phys. Chem., 1984, 88(12), 2614-2621.

21 S. Takahashi, L. A. Curtiss, D. Gosztola, N. Koura and M.-L. Saboungi, Molecular Orbital Calculations and Raman Measurements for 1-Ethyl-3-methylimidazolium Chloroaluminates, Inorg. Chem., 1995, 34(11), 2990-2993.

22 N. M. Rocher, E. I. Izgorodina, T. Rüther, M. Forsyth, D. R. MacFarlane, T. Rodopoulos, M. D. Horne and A. M. Bond, Aluminium Speciation in 1-Butyl-1-Methylpyrrolidinium Bis(trifluoromethylsulfonyl) amide/AlCl3 Mixtures, Chem. -Eur. J., 2009, 15(14), 3435-3447.

23 M. Hog, M. Schneider, G. Studer, M. Bäuerle, S. A. Föhrenbacher, H. Scherer and I. Krossing, An Investigation of the Symmetric and Asymmetric Cleavage Products in the System Aluminum Trihalide/1Butylimidazole, Chem. -Eur. J., 2017, 23(46), 11054-11066.

24 M. Hog, B. Burgenmeister, K. Bromberger, M. Schuster, S. Riedel and I. Krossing, First Investigations Towards the Feasibility of an $\mathrm{Al} / \mathrm{Br}_{2}$ Battery Based on Ionic Liquids, ChemElectroChem, 2017, 4(11), 2934-2942.

25 M. Hog, M. Schneider and I. Krossing, Synthesis and Characterization of Bromoaluminate Ionic Liquids, Chem. -Eur. J., 2017, 23(41), 9821-9830.

26 E. Rytter, H. A. Øye, S. J. Cyvin, B. N. Cyvin and P. Klæboe, Raman spectra of AlCl3-AlkCl and trends in species formation, J. Inorg. Nucl. Chem., 1973, 35(4), 1185-1198.

27 R. Huglen, F. W. Poulsen, G. Mamantov, R. Marassi and G. M. Begun, Raman spectral studies of elemental sulfur in $\mathrm{Al}_{2} \mathrm{Cl}_{6}$ and chloroaluminate melts, Inorg. Nucl. Chem. Lett., 1978, 14(4), 167-172.

28 G. Torsi, G. Mamantov and G. M. Begun, Raman spectra of the $\mathrm{AlCl}_{3}-\mathrm{NaCl}$ system, Inorg. Nucl. Chem. Lett., 1970, 6(6), 553-560.

29 C. J. Dymek, J. S. Wilkes, M. A. Einarsrud and H. A. Øye, Spectral identification of $\mathrm{Al}_{3} \mathrm{Cl}_{10}{ }^{-}$in 1-methyl-3ethylimidazolium chloroaluminate molten salt, Polyhedron, 1988, 7(13), 1139-1145.

30 B. Gilbert, H. Olivier-Bourbigou and F. Favre, Chloroaluminate Ionic Liquids: from their Structural Properties to their Applications in Process Intensification, Oil Gas Sci. Technol., 2007, 62(6), 745-759.

31 J. M. Slattery, C. Daguenet, P. J. Dyson, T. J. S. Schubert and I. Krossing, How to Predict the Physical Properties of Ionic Liquids: A Volume-Based Approach, Angew. Chem., Int. Ed., 2007, 46(28), 5384-5388.

32 T. Peppel, C. Roth, K. Fumino, D. Paschek, M. Köckerling and R. Ludwig, The Influence of Hydrogen-Bond Defects on the Properties of Ionic Liquids, Angew. Chem., Int. Ed., 2011, 50(29), 6661-6665. 